\title{
Fungi Associated with the Quince Borer, Coryphodema tristis (Drury) (Lepidoptera: Cossidae), in Grapevines
}

\author{
G.F.J. Höppner and J.H.S. Ferreira
}

Viticultural and Oenological Research Institute (VORI), Private Bag X5026, 7600 Stellenbosch, Republic of South Africa

Submitted for publication: June 1990

Accepted for publication: September 1990

Key words: Coryphodema tristis, quince borer, fungal association, grapevine

Fungal discolouration of wood was found associated with galleries of Coryphodema tristis in grapevines. The mean percentage damage caused by larvae and fungal discolouration was $14,8 \%$ and $13,5 \%$ respectively. Twelve fungal species were isolated from the discoloured region. None of these fungi were transmitted from one generation of the insect to the next.

The quince borer, Coryphodema tristis (Drury) is a wood borer found on various plants (Myburgh \& Basson, 1960). It is a destructive pest of grapevines in the South-Western Cape, boring in the trunks and arms (G.F.J. Höppner, unpublished data). Damage is caused by larvae whose activity is restricted to live wood older than one year. Larvae initially feed for a period of up to three months on the surface of the wood below the loose bark before boring into the deeper wood layers. This damage is accompanied by the discolouration of tissue surrounding the galleries, similar to that caused by fungi associated with dieback in grapevines (Ferreira 1988). Fungi responsible for rot and stain in wood were found to be associated with galleries of the cossid Prionoxystus robiniae (Peck) in oaks (Berry, 1978).

This study was undertaken to determine whether fungi are responsible for the discolouration associated with the galleries of $C$. tristis in grapevines. Furthermore, a possible association between these fungi and $C$. tristis was investigated.

\section{MATERIALS AND METHODS}

Determination of damage: Twelve to fifteen year old Chenin blanc vines, infested with $C$. tristis, were cut off approximately $200 \mathrm{~mm}$ above soil level in various vineyards in the Bottelary area near Stellenbosch in the South-Western Cape. To determine the damage done by larvae and fungi, five randomly chosen vines were cut into cross sections $30 \mathrm{~mm}$ in length. The respective damage due to larval excavation and fungal infestation (represented by discoloured wood) was visually estimated as a percentage of the surface area for each cross section.

The isolation and identification of fungi: To isolate the fungi associated with $C$. tristis, ten infested vines were cut longitudinally to display the larval galleries. From the visually decayed wood surrounding the galleries, 12 wood chips, ca 10 $\mathrm{x} 10 \times 5 \mathrm{~mm}$ in size, were removed from each vine. These chips were surface-sterilised in $0.5 \%$ sodium hypochlorite, rinsed in sterile water and placed on potato dextrose agar (PDA) in petri dishes. Previous experience indicated that PDA was effective in isolating fungal species from wood with dieback symptoms (Ferreira, 1988).

All plates were incubated at $25^{\circ} \mathrm{C}$ under a combination of cool white fluorescent and black light with a $12 \mathrm{~h}$ photoperiod.
After 7 days incubation, all fungi present were identified microscopically and stored on PDA slants in McCartney bottles. These were sent to the Mycological Unit, Plant Protection Research Institute, Pretoria, for the confirmation of identity.

Association between quince borer and fungi: To determine whether fungi are transmitted by any of the life stages of C. tristis, isolations were made from the interior and exterior of second and final instar larvae, adults and eggs. Fifteen second and 15 final instar larvae were collected from five vines by careful splitting of the wood. Each larva was removed with a sterile forceps and rolled on PDA in a petri dish. The same larvae were then surface-sterilised in $0,5 \%$ sodium hypochlorite and dissected to remove the digestive tract contents. These were placed on PDA in petri dishes. Isolations from the surface of 15 field-collected adults that had emerged from infested grapevines, and their ovaries, and from the surface and contents of 30 eggs, laid on grapevines in a natural infestation, were made as described for larvae. The incubation and identification of fungi were carried out as described previously.

\section{RESULTS AND DISCUSSION}

Determination of damage: The damage caused by larvae plus fungi per cross section $(\mathrm{n}=576)$ ranged from $0 \%$ to $95 \%$, with a mean of $28,3 \%(\mathrm{SD}=19,7 \%)$ for all grapevines. The mean damage done by larvae was $14,8 \%(\mathrm{SD}=10,85 \%)$, whereas fungal discolouration contributed $13,5 \%(\mathrm{SD}=13,6 \%)$. This great variation can be ascribed to the fact that the most damage occurred on the higher part of the trunk and the adaxial parts of the arms.

It appeared that $C$. tristis larvae, after entering the wood, first attack the pith before expanding the galleries to the adjoining wood. In fresh galleries the discoloured area around galleries was narrow $( \pm 2 \mathrm{~mm})$, but this expanded as galleries aged. In some cases the discoloured area extended outwards in a wedge shape.

The isolation and identification of fungi: Twelve fungal species were isolated from discoloured areas surrounding border galleries (Fig 1). Trichoderma harzianum, Penicillium purpurascens, Cephalosporium spp.,Fusarium oxyporum and Pestalotia quepini occurred most frequently. Of the isolated

S. Afr. J. Enol. Vitic., Vol. 11, No. 2, 1990 


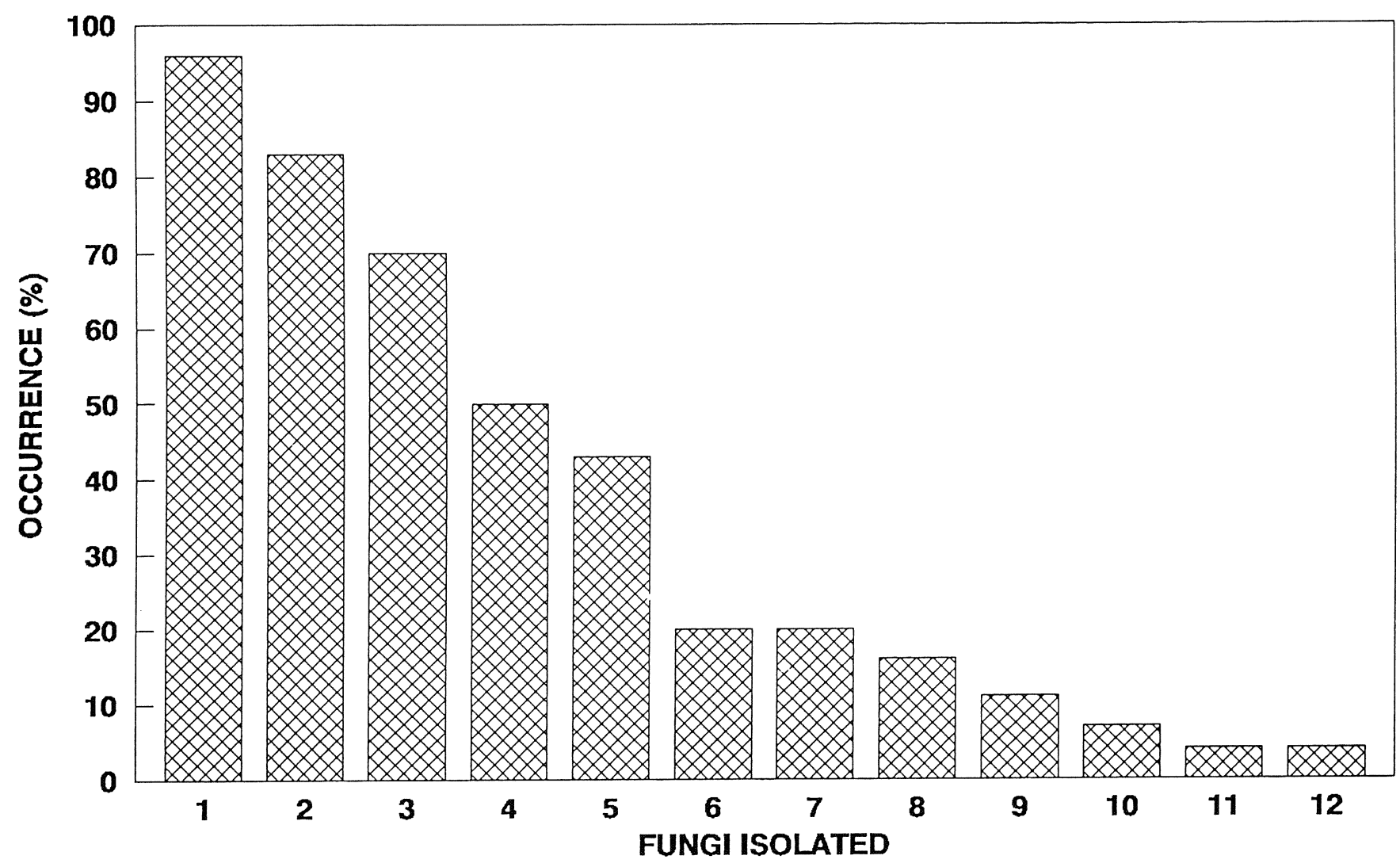

FIGURE 1

Percentage occurrence of fungi isolated from decayed grapevine wood surrounding larval galleries of Coryphodema tristis. $1=$ Trichoderma harzianum, $2=$ Penicillium purpurascens, $3=$ Cephalosporium sp., $4=$ Fusarium oxysporum, $5=P$ estalotia quepini, $6=$ Alternaria alternata, $7=$ Rhizopus sp., $8=$ Gliocladium sp., $9=$ Aspergillus sp., $10=$ Epicoccum purpurascens, 11 = Botrytis cinerea, 12 = Sphaeropsis sp.

TABLE 1

Fungi isolated from different stages of Coryphodema tristis and frequency of occurrence.

\begin{tabular}{|c|c|c|c|c|c|c|c|c|}
\hline \multirow{3}{*}{ Fungi isolated } & \multicolumn{8}{|c|}{ Occurrence $(\%)$} \\
\hline & \multicolumn{4}{|c|}{ External } & \multicolumn{4}{|c|}{ Internal } \\
\hline & $\begin{array}{l}\text { second instar } \\
\text { larvae }\end{array}$ & $\begin{array}{c}\text { final instar } \\
\text { larvae }\end{array}$ & adults & eggs & $\begin{array}{c}\text { second instar } \\
\text { larvae }\end{array}$ & $\begin{array}{c}\text { final instar } \\
\text { larvae }\end{array}$ & ovaries & eggs \\
\hline $\begin{array}{l}\text { Penicillium } \\
\text { purpurascens }\end{array}$ & 80,0 & 100,0 & 100,0 & 100,0 & 13,3 & 6,7 & 0 & 0 \\
\hline Cephalosporium sp. & 46,7 & 33,3 & 0 & 0 & 53,3 & 33,3 & 0 & 0 \\
\hline $\begin{array}{l}\text { Epicoccum } \\
\text { purpurascens }\end{array}$ & 46,7 & 20,0 & 0 & 0 & 0 & 0 & 0 & 0 \\
\hline $\begin{array}{l}\text { Trichoderma } \\
\text { harzianum }\end{array}$ & 46,7 & 13,3 & 0 & 0 & 0 & 0 & 0 & 0 \\
\hline Alternaria alternata & 33,3 & 53,3 & 0 & 0 & 0 & 6,7 & 0 & 0 \\
\hline Aspergillus sp. & 13,3 & 46,7 & 0 & 0 & 0 & 46,6 & 0 & 0 \\
\hline Rhizopus sp. & 6,7 & 0 & 0 & 0 & 0 & 0 & 0 & 0 \\
\hline $\begin{array}{l}\text { Fusarium } \\
\text { oxysporum }\end{array}$ & 0 & 86,6 & 0 & 0 & 0 & 0 & 0 & 0 \\
\hline
\end{tabular}


fungi, however, only Cephalosporium spp., F. oxysporum, $P$. quepini, Botrytis cinerea and Sphaeropsis spp. can act parasitically, whereas the others are saprophytes. The occurrence of $B$. cinerea and Sphaeropsis spp. was very low however, indicating that their role in colonising the wood was negligible. Ferreira (1988) found nine of these fungi to be associated with dieback and pruning wounds, and Hansen (1985) named Cephalosporium spp. as some of several fungi responsible for wood decay in grapevines.

Association between quince borer and fungi: During regular sampling of $C$. tristis infested grapevines it was found that larvae drowned in phloem exudates that filled galleries where discoloured wood was absent. Wood-colonising fungi may be responsible for the lowring of moisture in the wood surrounding the galleries, creating a favourable habitat for the development of the larvae. The loss of moisture not only facilitates wood-border invasion but also results in the increased aeration of the microhabitat from which the insects must obtain oxygen for respiration (Graham, 1967). It, therefore, appeared that the fungi may play an important role in the survival of $C$. tristis larvae.

Fungi isolated and their frequency of occurrence on the exterior of larvae, adults and eggs, in the digestive tracts of larvae and in ovaries and eggs are listed in Table 1. The presence of fungi on the surface and in the digestive tract of larvae indicated that the fungi can be transmitted to the deeper layers of the wood. However, no fungi were present in eggs and ovaries which indicates that there was no anatomical adaptation in the insect for the transfer of the fungi from one generation to the next. Penicillium purpurascens was the only fungus present on adults and eggs. This fungus may have been transmitted from the adults to the eggs by scales shed during oviposition. Therefore, there was no behavioural or anatomical adaptation in the insect for the transfer of the fungi from one generation to the next. It is assumed that the fungal infection of the wood occurred after wounding during the initial feeding of neonate larvae on the surface and under the loose bark. The lengthy initial period of feeding would allow the fungi to penetrate the wood and create a favourable environment for the survival of the larvae, thus enabling larvae to penetrate the deeper layers of the wood.

It appears that the association between $C$. tristis and the fungi can best be described as protoco-operation: the fungi create a favourable environment for larval survival in the wood but can colonise and develop in vinewood in the absence of $C$. tristis (Ferreira, 1988), while, on the other hand, they benefit in that the larval wounding of wood supplies entrance holes and larvae aid in their dispersal.

\section{CONCLUSIONS}

Appreciable fungal decay was associated with borer galleries in grapevines. The isolated fungi apparently played an important role in the ecology of the larvae in that they created a favourable environment for their survival. However, none of the fungi isolated from discoloured wood were transmitted from one generation of the insect to the next since they were not present in or on the adults or eggs. Also, they are not dependent on borers for infection of the wood. It thus seems that protoco-operation exists between $C$. tristis and the fungi isolated.

\section{LITERATURE CITED}

BERRY, F.H., 1978. Decay associated with borer wounds in living oaks Forest Res. Notes N East. Forest Exp. Stn. NE-268.

FERREIRA, J.H.S., 1988. Dieback of grapevines in South Africa. Ph.D. dissertation, University of the Western Cape, Private Bag X117, 7530 Bellville, Republic of South Africa.

GRAHAM, K., 1967. Fungal-insect mutualism in trees and timber. Annu. Rev Entomol. 12, 105-126.

HANSEN, J.D., 1985. Common names for plant diseases. Plant Dis. 69, 649676.

MYBURGH, A.C. \& BASSON, S.G., 1960. The quince and apple borer. Decid. Fruit Grow. 10, 331-333. 